\title{
Phosphate Solubilizing-based Peat Soil Carier Applied to Potato
}

\author{
Linlin Parlinah $^{1 *}$, Jajang Sauman Hamdani ${ }^{2}$, Anne Nurbaety ${ }^{2}$ and Anne Nuraini ${ }^{1}$ \\ Date Received: $18^{\text {th }}$ December 2019 / Date Accepted: $27^{\text {th }}$ January 2020
}

\begin{abstract}
Purpose : The indigenous phosphate solubilizing stored in peat soil as a carier is still a prospect as an ingredient of biological fertilizer, so it still needs to review how the indigenus phosphate solubilizing area of Tanjungsari, Sumedang worthy to be used as an ingredient Biological fertilizer.

Research Method: The experiment was conducted at the Faculty of Agriculture Univeritas Winaya Mukti with the land type Andisol and the altitude of $850 \mathrm{~m}$ asL, carried out in March to June 2019. Environmental design using random draft group combination repeated 3 times with treatment consists of 13 treatments that are a type of phosphate solubilizing combined with a dose of peat soil carier. The data was analyzed further with Duncan's test at $5 \%$.

Findings : Results showed that the Tanjungsari's indigenus phosphate solubilizing with peat soil effect on the Phosphate is available on the soil, Phosphate total domain, potato shoot root ratio, number of the cropping bulbs, the weight of the tuber per plant and the weight per tuber, but has no effect on $\mathrm{pH}$ Soil, bacterial population, cation exchange capacity soils and absorption Phosphate in plants.
\end{abstract}

Limitations : This research is done at medium place height where not the optimum altitude for potato.

Value : Phosphate solubilizing bacteria indigenous from Tanjungsari Sumedang with carrier materials peat soil has the potential to be used organic fertilizer.

Keywords: Peat soil carier, phosphate solubilizing, potato

\section{INTRODUCTION}

The provision of inorganic fertilizer in Indonesia is still highly dependent on subsidies issued by governments. The use of unbalanced inorganic fertilizer creates damage to farmland. The use of organic materials enriched with microorganisms is very important, it is one way to reduce the use of excess inorganic fertilizer (Mareckova, Ondrej, Omelka, Kristufek, \& Divis, 2015; Oteino et al., 2015; Sudadi, Widijanto, \& Hahsari Efendi Putri, 2008; Uddin et al., 2014). The use of organic materials has the potential to increase potato production toward sustainable agriculture (Ekin, 2019).

Organic fertilizer enriched by microorganisms depends on the carrier material. The composition of carrier media such as manure, sand soil is able to increase the availability of phosphate nutrients in soil (Firdausi et al., 2016). Phosphate solubilizing bacteria incorporated into the carrier material of peat soil can withstand up to 7 weeks on storage period (Raharjo \& Suprihadi, 2010). The sterilization process of the carrier after inoculation of the phosphate solubilizing will lead to a decrease in the phosphate population in carrying materials (Putri, Anas, \& Hazra, 2010). The suitability combination of the inoculated phosphate solubilizing bacteria affects the increase in potato production (Santiago et al., 2017). The use of chemical fertilizers can reduce soil aggregate levels, and microbial populations while the use of biofertilizer and chemical fertilizers is better

\footnotetext{
1 Agricultural Faculty of Universitas Winaya Mukti, Indonesia. linlinparlinah@unwim.ac.id

2 Agricultural Faculty of Universitas Padjadjaran, Indonesia.

(D) ORCID http://orcid.org/0000-0003-2916-7596
} 
in terms of microbial respiration and potato yield (Zabee \& AL-Maliki, 2019).

It should be sterilized by autoclaving method of the carrier before the process of inoculation of the phosphate solubilizing bacteria so as not to reduce the number of bacterial populations in carrier material. So that the combination of phosphate solubilizing bacteria type with a dose of peat soil carrying material is able to give influence when inoculated in potatoes.

\section{MATERIALS AND METHODS}

The trial was carried out in the experimental Garden Faculty of Agriculture University of Winaya Mukti, in March to June 2019 with the order of land of Andisol and the altitude of place $850 \mathrm{~m}$ above. Phosphate solubilizing used results from the isolation of Tanjungsari area, Sumedang (Pseudacidovorax intermedius, Agrobacterium fabrum, Agrobacterium tumefaciens, and Serratia Nematodiphila). The seeds of potatoes used are varieties of Medians second generation.

\section{Production of bacterial}

Inoculation that has been in the multitude and in inalignment for 24 hours on the media to oblique Pikovskaya, ininated in liquid Pikovskaya media. $10 \mathrm{ml}$ of physiological $\mathrm{NaCl} 0.85 \%$ inserted to the incline containing bacteria, culprit until the bacteria did not stick on it to tilt. Input into medium $300 \mathrm{ml}$ liquid pikovskaya Media, shake using shaker with speed $112 \mathrm{rpm}$ at room temperature for 72 hours (for 3 days). The amount of phosphate solubilizing in liquid Pikovkaya solution reaches 109, hereinafter applied to the carrier material.

\section{Inoculation process}

Bacteria that have been in the bunch and in inubility for 24 hours on the media to oblique Pikovskaya, ininated in liquid Pikovskaya media. $10 \mathrm{ml}$ of physiological $\mathrm{NaCl} 0.85 \%$ inserted to the incline containing bacteria, culprit until the bacteria did not stick on it to tilt. Input into medium $300 \mathrm{ml}$ liquid pikovskaya Media, shake using shaker with speed $112 \mathrm{rpm}$ at room temperature for 72 hours (for 3 days). The amount of phosphate solubilizing in liquid Pikovkaya solution reaches 109, hereinafter applied to the carrier material.

\section{Inoculation process}

The carrying materials of peat soil are sterilised first before it is inoculated so that the amount of the foosfat solubilizing that will be incubated is not decreased (Putri et al., 2010). As much as $2 \mathrm{~kg}$ of peat soil with the smoothness of the material passes 100 mesh sieve, input plastic and in Strerilisais use autokalf with a temperature of 1210 for 60 minutes. Mixing phosphate solubilizing into the carrier material in Laminer water flow, $210 \mathrm{ml}$ of pikovskaya liquid media in mix into the carrier material added aquades $300 \mathrm{ml}$, and fertilizer SP36 200 g. Then incubated for three days. and calculated population count The bacteria with the Total Plate Count method, after which can be applied to plants.

\section{Inoculation of potatoes}

The design of the environment used is the random design of the combination group repeated 3 times. The treatment consists of a type of phosphate solubilizing combined with the following dose of Carier: A (Control); B (phosphate solubilizing Pseudacidovorax intermedius dose $50 \mathrm{Kg}$ ha-1); C (phosphate solubilizing Agrobacterium fabrum phosphate dose $50 \mathrm{Kg}$ ha-1); D (phosphate solubilizing Agrobacterium tumefaciens dose $50 \mathrm{Kg}$ ha-1); E (phosphate solubilizing Serratia nematodiphila doses $50 \mathrm{Kg}$ ha-1); F (phosphate solubilizing Pseudacidovorax intermedius dose $100 \mathrm{Kg}$ ha1); G (phosphate solubilizing Agrobacterium fabrum dose $100 \mathrm{Kg}$ ha-1); $\mathrm{H}$ (phosphate solubilizing Agrobacterium tumefaciens dose $100 \mathrm{Kg}$ ha-1); I (phosphate solubilizing nematodiphila Serratia dose $100 \mathrm{Kg}$ ha-1); J (phosphate solubilizing Pseudacidovorax intermedius dose $150 \mathrm{Kg}$ ha-1); $\mathrm{K}$ (phosphate solubilizing Agrobacterium fabrum dose $150 \mathrm{Kg}$ ha-1); L (phosphate solubilizing Agrobacterium tumefaciens dose $150 \mathrm{Kg}$ ha-1), M (solubilizing phosphate Serratia nematodiphila dose 150 $\mathrm{Kg}$ ha-1). The analyzed response is the potato shoot root ratio, the number of bulbs per plant, 
the weight of the tuber per plant, the weight per tuber, $\mathrm{P}$ total soil (Olsen method), $\mathrm{P}$ available on the soil (the method of Bray I), KTK (leaching method Ammonium acetate $1 \mathrm{~N}$ pH 7), $\mathrm{pH} \mathrm{H} 2 \mathrm{O}$ (Electometry method), Number of bacteria (Total plate count method) and $\mathrm{P}$ uptake in plants (wet oxidation method HNO3 and HCLO4). Chemical fertilization is given half the recommended NPK fertilizer $(200 \mathrm{~kg}$ ha-1 N, $150 \mathrm{~kg}$ ha-1 P2O5 and $150 \mathrm{~kg}$ ha-1 K2O). Potatoes are harvested at the age of 90 days after planting.

Table 01: $\quad$ Population number of phosphate solubilizing bacteria on peat soil carrying materials on application time to potatoes and number of phosphate solubilizing bacteria in peat soil carrier material after 3 months of storage

Types of phosphate solubilizing
bacteria

Number of phosphate solubilizing bacteria on peat soil carrying materials

Number of phosphate solubilizing bacteria on carrier materials after stored for 3 months

Pseudacidovorax intermedius

Agrobacterium fabrum

Agrobacterium tumefaciens

Serratia nematodiphila
$2.56 \times 10^{7} \mathrm{CFU} / \mathrm{g}$

$2.95 \times 10^{7} \mathrm{CFU} / \mathrm{g}$

$2.51 \times 10^{7} \mathrm{CFU} / \mathrm{g}$

$1.81 \times 10^{7} \mathrm{CFU} / \mathrm{g}$

Table 02: Combination of phosphate solubilizing type with carier dose of $P$ total soil, $P$ available, NPA, number of bulbs per plant, tuber weight per plant and weight per plant

\begin{tabular}{ccccccccccccc}
\hline Treatment & \multicolumn{2}{c}{$\begin{array}{c}\text { Total soil } \\
\text { phosphate }\end{array}$} & \multicolumn{2}{c}{$\begin{array}{c}\text { Phosphate } \\
\text { available }\end{array}$} & $\begin{array}{c}\text { Root extinct } \\
\text { ratio }\end{array}$ & $\begin{array}{c}\text { Number of } \\
\text { bulbs per plant }\end{array}$ & $\begin{array}{c}\text { Tuber weight } \\
\text { per plant }\end{array}$ & $\begin{array}{c}\text { Weight per } \\
\text { tuber }\end{array}$ \\
\hline $\mathrm{A}$ & 4993.3 & $\mathrm{a}$ & 13.62 & $\mathrm{ab}$ & 3.878 & $\mathrm{~b}$ & 5.67 & $\mathrm{a}$ & 162.22 & $\mathrm{a}$ & 35.52 & $\mathrm{a}$ \\
$\mathrm{B}$ & 3992.6 & $\mathrm{a}$ & 18.67 & $\mathrm{ab}$ & 2.610 & $\mathrm{ab}$ & 5.89 & $\mathrm{a}$ & 242.78 & $\mathrm{ab}$ & 48.66 & $\mathrm{a}$ \\
$\mathrm{C}$ & 5996.4 & $\mathrm{a}$ & 18.44 & $\mathrm{ab}$ & 2.455 & $\mathrm{ab}$ & 6.11 & $\mathrm{a}$ & 365.33 & $\mathrm{~b}$ & 49.57 & $\mathrm{a}$ \\
$\mathrm{D}$ & 2808.8 & $\mathrm{a}$ & 15.72 & $\mathrm{ab}$ & 1.919 & $\mathrm{a}$ & 4.67 & $\mathrm{a}$ & 342.00 & $\mathrm{ab}$ & 67.68 & $\mathrm{a}$ \\
$\mathrm{E}$ & 5446.5 & $\mathrm{a}$ & 15.46 & $\mathrm{ab}$ & 2.479 & $\mathrm{ab}$ & 4.33 & $\mathrm{a}$ & 255.56 & $\mathrm{ab}$ & 72.57 & $\mathrm{a}$ \\
$\mathrm{F}$ & 2816.3 & $\mathrm{a}$ & 15.90 & $\mathrm{ab}$ & 2.350 & $\mathrm{ab}$ & 6.22 & $\mathrm{a}$ & 523.89 & $\mathrm{c}$ & 89.31 & $\mathrm{~b}$ \\
$\mathrm{G}$ & 5939.4 & $\mathrm{a}$ & 19.52 & $\mathrm{ab}$ & 2.446 & $\mathrm{ab}$ & 7.00 & $\mathrm{~b}$ & 363.33 & $\mathrm{~b}$ & 44.31 & $\mathrm{a}$ \\
$\mathrm{H}$ & 5812.9 & $\mathrm{a}$ & 13.18 & $\mathrm{ab}$ & 2.821 & $\mathrm{ab}$ & 5.89 & $\mathrm{a}$ & 408.33 & $\mathrm{~b}$ & 48.64 & $\mathrm{a}$ \\
$\mathrm{I}$ & 3861.9 & $\mathrm{a}$ & 18.02 & $\mathrm{ab}$ & 2.454 & $\mathrm{ab}$ & 6.11 & $\mathrm{a}$ & 356.00 & $\mathrm{~b}$ & 52.38 & $\mathrm{a}$ \\
$\mathrm{J}$ & 3423.0 & $\mathrm{a}$ & 17.13 & $\mathrm{ab}$ & 2.492 & $\mathrm{ab}$ & 5.22 & $\mathrm{a}$ & 327.78 & $\mathrm{ab}$ & 49.11 & $\mathrm{a}$ \\
$\mathrm{K}$ & 4233.3 & $\mathrm{a}$ & 25.04 & $\mathrm{~b}$ & 2.553 & $\mathrm{ab}$ & 7.33 & $\mathrm{~b}$ & 403.11 & $\mathrm{~b}$ & 48.14 & $\mathrm{a}$ \\
$\mathrm{L}$ & 14407.9 & $\mathrm{~b}$ & 19.45 & $\mathrm{ab}$ & 2.319 & $\mathrm{ab}$ & 5.89 & $\mathrm{a}$ & 356.11 & $\mathrm{~b}$ & 51.71 & $\mathrm{a}$ \\
$\mathrm{M}$ & 2939.5 & $\mathrm{a}$ & 11.29 & $\mathrm{a}$ & 2.798 & $\mathrm{ab}$ & 5.22 & $\mathrm{a}$ & 293.56 & $\mathrm{ab}$ & 61.32 & $\mathrm{a}$ \\
\hline
\end{tabular}


Table 03: Combination of phosphate solubilizing type with carier dose of $\mathrm{pH}$, number of bacteria, cation exchange capacity and absorption $P$ plant.

\begin{tabular}{|c|c|c|c|c|c|c|c|c|}
\hline \multirow{2}{*}{$\frac{\text { Treatment }}{\mathrm{A}}$} & \multicolumn{2}{|l|}{ Soil pH } & \multicolumn{2}{|c|}{$\begin{array}{c}\text { Number of bacteria } \\
(\mathrm{CFU} / \mathrm{g})\end{array}$} & \multicolumn{2}{|c|}{$\begin{array}{l}\text { Cation Exchange } \\
\text { capacity }\end{array}$} & \multicolumn{2}{|c|}{$\begin{array}{c}\text { Absorption } \\
\text { Pphosphate Plant }\end{array}$} \\
\hline & 5.07 & $\mathrm{a}$ & 1.57 & $\mathrm{a}$ & 29.27 & $\mathrm{a}$ & 8.56 & $\mathrm{a}$ \\
\hline $\mathrm{B}$ & 5.15 & $\mathrm{a}$ & 1.42 & $\mathrm{a}$ & 29.53 & $\mathrm{a}$ & 14.38 & $\mathrm{a}$ \\
\hline $\mathrm{C}$ & 5.05 & $\mathrm{a}$ & 0.95 & $\mathrm{a}$ & 28.80 & $\mathrm{a}$ & 20.25 & $\mathrm{a}$ \\
\hline $\mathrm{D}$ & 4.96 & $\mathrm{a}$ & 1.31 & $\mathrm{a}$ & 31.27 & $\mathrm{a}$ & 9.34 & $\mathrm{a}$ \\
\hline E & 5.03 & $\mathrm{a}$ & 1.07 & $\mathrm{a}$ & 27.20 & $\mathrm{a}$ & 9.46 & $\mathrm{a}$ \\
\hline F & 5.01 & $\mathrm{a}$ & 1.54 & $\mathrm{a}$ & 28.40 & $\mathrm{a}$ & 10.32 & $\mathrm{a}$ \\
\hline G & 4.97 & $\mathrm{a}$ & 1.49 & $\mathrm{a}$ & 29.00 & $\mathrm{a}$ & 16.61 & $\mathrm{a}$ \\
\hline $\mathrm{H}$ & 5.27 & $\mathrm{a}$ & 1.86 & $\mathrm{a}$ & 30.67 & $\mathrm{a}$ & 6.71 & $\mathrm{a}$ \\
\hline I & 4.85 & $\mathrm{a}$ & 1.47 & $\mathrm{a}$ & 28.67 & $\mathrm{a}$ & 5.54 & $\mathrm{a}$ \\
\hline $\mathrm{J}$ & 4.97 & $\mathrm{a}$ & 1.49 & $\mathrm{a}$ & 27.93 & $\mathrm{a}$ & 7.57 & $\mathrm{a}$ \\
\hline K & 5.23 & $\mathrm{a}$ & 1.14 & $\mathrm{a}$ & 29.13 & $\mathrm{a}$ & 13.19 & $\mathrm{a}$ \\
\hline L & 4.94 & $\mathrm{a}$ & 1.56 & $\mathrm{a}$ & 29.07 & $\mathrm{a}$ & 11.51 & $\mathrm{a}$ \\
\hline M & 5.20 & $\mathrm{a}$ & 1.43 & $\mathrm{a}$ & 30.73 & $\mathrm{a}$ & 16.60 & $\mathrm{a}$ \\
\hline
\end{tabular}

Soil nutrient content before the study of $\mathrm{pH}$ $\mathrm{H}_{2} \mathrm{O}$ 6.82, C-Organic 4.01\% (high), N-Total $0.33 \%$ (moderate), $\mathrm{C} / \mathrm{N} 12$ (moderate), $\mathrm{P}_{2} \mathrm{O}_{5}$ $37.13 \mathrm{mg} / 100 \mathrm{~g}$ (medium), $\mathrm{K}_{2} \mathrm{O}_{5} 39.69 \mathrm{mg} / 100 \mathrm{~g}$ (moderate), cation exchange capacity 24.9 (moderate). The type of phosphate solubilizing bacteria in the peat soil carrying material with a dose of inocculated carrier material on the potatoes affects the total $\mathrm{P}$ soil, $\mathrm{p}$ is available on the ground, root extinct ratio, number of cropping bulbs, the weight of the land bulbs and weights Per tuber (table 02). The type of phosphate solubilizing Agrobacterium tumefaciens dose $150 \mathrm{Kg} \mathrm{ha}{ }^{-1}$ is able to increase $\mathrm{P}$ total soil highs. Phosphate solubilizing bacteria have the ability to produce extracellular enzymes such as phosphatase. This enzyme is able to mineralize organic phosphate into inorganic phosphate which provides high $\mathrm{P}$ for the plant $(\mathrm{Li}, \mathrm{Wu}$, Ye, \& Yang, 2018). Agrobacterium fabrum dose $150 \mathrm{Kg} \mathrm{ha}^{-1}$ is able to increase $\mathrm{P}$ available on soil and the number of highest bulbs. According to Panhwar et al., (2013) posfat solubilizing bacteria are able to increase $\mathrm{P}$ available in soil without affecting soil pH. Meyer et al., (2018) adds that the Agrobacterium fabrum bacteria are able to symbiosis in plant rhizospere. Phosphate solubilizing Pseudacidovorax intermedius dose $100 \mathrm{Kg} \mathrm{ha}^{-1}(\mathrm{~F})$ is able to increase the weight of the tuber per plant and the highest of the weight. Souza et al., (2013) also reported that the administration of Pseudacidovorax intermedius combined with chemical fertilizer half of the recommended fertilizer for rice plants is able to increase the growth of the same as recommended dose fertilizer. Wedage at al., (2019)ditemukan terutama di zona basah Sri Lanka. Fiksasi nitrogen dilakukan oleh penduduk nodular dari tanaman penutup ini, sebanding dengan bakteri nodule-tinggal dari kebanyakan tanaman kacang-kacangan lainnya. Kami mengisolasi bakteri (Sub1 added that Pseudacidovorax intermedius impases indole acetic acid and produces the production of nitrogenase enzymes. The phosphate solubilizing Agrobacterium tumefaciens dose $50 \mathrm{Kg}$ ha $^{-1}$ (D) is given indicating the most small root extinct ratio of this which indicates that the plant growth is more balanced when compared to the control where the root of a extinct is larger so that more growth into the pupus. All treatments show the growth of the root part is better than the control, White et al., (2018) explains the root power of potatoes affecting the plant acquired phosphate. Phosphate solubilizing bacteria are able to dissolve the insoluble phosphate thereby encouraging plant growth (Yang et al., 2018). Phosphoric administration has an impact on the increase of potato yield, in accordance with the results of the experiment where the treatment is able to improve the number of bulbs per plant, the weight of cropping bulbs and bulbs per Plant (Debaba, Hartono, Sudadi, \& Indriyati, 2019; Soratto, Fernandes, Pilon, \& Souza, 2019). 
Types of phosphate solubilizing bacteria in peat soil carrying material with a dose of inoculated carrier material in potatoes has no effect on soil $\mathrm{pH}$, number of bacteria, cation exchange capacity and absorption $\mathrm{P}$ plant (table 03). The provision of biological fertilizer with the addition of half the recommended dose of chemical fertilizer does not increase soil $\mathrm{pH}$, this is in line with the results of research Eissa (2019) where chemical fertilizer can reduce soil $\mathrm{pH}$. The soil $\mathrm{pH}$ was preliminary before the 6.82 experiment, and after the soil $\mathrm{pH}$ experiment the initial $\mathrm{pH}$ value for all treatment is shown below. The number of bacteria in the soil does not show any different results with the control, which according to Guimere et al., (2019), the availability of $\mathrm{P}$ soil that will affect the level of bacteria interaction. All of the treatment showed that it is able to provide the availability of phosphate in soil but not different from the control so, it shows the number of bacteria that does not differ also by control. The value of the cation exchange rate at the beginning of the test indicates moderate (24.9), so the provision of the entire treatment does not show different results with control. Phosphate uptake of plants throughout the treatment shows results that are not different from the control, where according to Potarzycki \& Grzebisz (2019) phosphate is not a factor that limits the growth of potatoes where phosphate content in the bulbs is smaller.

\section{CONCLUSION}

The results showed that the solubilizing indigenous phosphate of Tanjungsari with peat soil carrier as the potential organic fertilizer. The treatment of organic fertilizer is able to increase the phosphate available on $188.5 \%$ soil, total soil phosphate $83.11 \%$, potato shoot root ratio, number of cropping bulbs $29.4 \%$, bulb weight per plant $222,9 \%$ and the weight per tuber $151.4 \%$, but has no effect on soil $\mathrm{pH}$, Bacterial populations, soil cation exchange capacity and absorption of phosphate in plants.

\section{Data Availability Statement}

The datasets generated during and/or analysed during the current study are available from the corresponding author on a reasonable request.

\section{ACKNOWLEDGMENTS}

The author would like to thank BUDILPDP as a contributor to the research Fund, mentor lecturer at the Faculty of Agriculture, Universitas Padjadjaran, Faculty of Agriculture at Winaya Mukti University.

\section{REFERENCE}

Debaba, G. H., Hartono, A., Sudadi, U., \& Indriyati, L. T. (2019). Establishing soil phosphorus critical level for potato (Solanum tuberosum L.) in Andisol of Lembang, Indonesia. International Society for Southeast Asian Agricultural Sciences, 25(1), 11-20. Retrieved from https://www.cabdirect.org/cabdirect/abstract/20193361895

Eissa, M. A. (2019). Efficiency of P Fertigation for Drip-Irrigated Potato Grown on Calcareous Sandy Soils. Potato Research, 62(1), 97-108. Retrieved from https://link.springer.com/ article/10.1007/s11540-018-9399-7. DOI: https://doi.org/10.1007/s11540-018-9399-7

Ekin, Z. (2019). Integrated Use of Humic Acid and Plant Growth Promoting Rhizobacteria to Ensure Higher Potato Productivity in Sustainable Agriculture. Sustainability, 11(12), 1-13. DOI: https://doi.org/10.3390/su11123417

Firdausi, N., Muslihatin, W., Nurhidayati, T., Biologi, J., Matematika, F., Alam, P., ... Indonesia, S. (2016). Pengaruh Kombinasi Media Pembawa Pupuk Hayati Bakteri Pelarut Fosfat Tehadap pH dan Unsur Hara Fosfor dalam Tanah. Jurnal Sains Dan Seni ITS, 5(2), 2337-3520. Retrieved from http://ejurnal.its.ac.id/index.php/sains_seni/article/download/20634/2884. DOI: https://doi.org/10.12962/j23373520.v7i2.37241 
Gumiere, T., Rousseau, A. N., Costa, D. P. da, Cassetari, A., \& Cotta, S. R. (2019). Phosphorus source driving the soil microbial interactions and improving sugarcane development. Scientific Reports (Nature Publisher Group), 9, 1-9. DOI: https://doi.org/10.1038/s41598019-40910-1

Li, G.-X., Wu, X.-Q., Ye, J.-R., \& Yang, H.-C. (2018). Characteristics of Organic Acid Secretion Associated with the Interaction between Burkholderia multivorans WS-FJ9 and Poplar Root System. BioMed Research International, 2018, 1-12. DOI: https://doi. org/10.1155/2018/9619724

Mareckova, M. S., Ondrej, D., Omelka, M., Kristufek, V., \& Divis, J. et al., (2015). Determination of Factors Associated with Natural Soil Suppressivity to Potato Common Scab. PLoS One, 10(1), 1-13.DOI: https://doi.org/10.1371/journal.pone.0116291

Meyer, T., Renoud, S., Vigouroux, A., Miomandre, A., Gaillard, V., Kerzaon, I., ... Lavire, C. (2018). Regulation of Hydroxycinnamic Acid Degradation Drives Agrobacterium fabrum Lifestyles. Molecular Plant-Microbe Interactions : MPMI, 31(8), 814-822. DOI: https://doi. org/10.1094/mpmi-10-17-0236-r

Oteino, N., Lally, R. D., Kiwanuka, S., Lloyd,A., Ryan, D., Germaine, K. J., \& Dowling, D. N.(2015). Plant growth promotion induced by phosphate solubilizing endophytic Pseudomonas isolates. Frontiers in Microbiology, 6(JUL), 1-9. DOI: https://doi.org/10.3389/fmicb.2015.00745

Panhwar, Q. A., Jusop, S., Naher, U. A., Othman, R., Razi, M. I., Andrade, P., \& Zhou, D. (2013). Application of Potential Phosphate-Solubilizing Bacteria and Organic Acids on Phosphate Solubilization from Phosphate Rock in Aerobic Rice. The Scientific World Journal, 2013, 1-10. DOI: https://doi.org/10.1155/2013/272409

Potarzycki, J., \& Grzebisz, W. (2019). Trends In Phosphorus Concentrations In Potato Organs During The Growing Season. Journal of Elementology, 24(3), 935-952. DOI: https://doi. org/10.5601/jelem.2019.24.1.1777

Putri, S. M., Anas, I., \& Hazra, F. (2010). Viabilitas Inokulan dalam Bahan Pembawa Gambut, kompos, Arang Batok dan Zeolit yang Disteril dengan Iradiasi Sinar Gamma Co-60 DAN Mesin Berkas Elektron; Viability of Inoculant in Peat, Compost, Coconut Shell Charcoal and Zeolite Sterilized by Gamma Irr. Jurnal Tanah Dan Lingkungan, 12(1), 23-30. Retrieved from http://jagb.journal.ipb.ac.id/index.php/jtanah/article/view/16593. DOI: https://doi. org/10.29244/jitl.12.1.23-30

Raharjo, B., \& Suprihadi, A. (2010). Mix Culture Inoculant Production of Phosphate Solubilyzing and Indole Acetic Acid (IAA) Producer Rhizobacteria with Ambarawa Peat Soil Rawapening As Carrier. Jurnal Sains \& Matematika (JSM), 18(2), 69-81. Retrieved from http://www. ejournal.undip.ac.id/index.php/sm/article/view/3138

Santiago, C. D., Yagi, S., Ijima, M., Nashimoto, T., Sawada, M., Ikeda, S., ... Ohwada, T. (2017). Bacterial Compatibility in Combined Inoculations Enhances the Growth of Potato Seedlings. Microbes and Environments, 32(1), 14-23.DOI: https://doi.org/10.1264/jsme2.me16127

Soratto, R. P., Fernandes, A. M., Pilon, C., \& Souza, M. R. (2019). Phosphorus and silicon effects on growth, yield, and phosphorus forms in potato plants. Journal of Plant Nutrition, 42(3), 218-233. DOI: https://doi.org/10.1080/01904167.2018.1554072 
Souza, R. de, Beneduzi, A., Ambrosini, A., da Costa, P. B., Meyer, J., Vargas, L. K., .. Passaglia, L. M. P. (2013). The effect of plant growth-promoting rhizobacteria on the growth of rice (Oryza sativa L.) cropped in southern Brazilian fields. Plant and Soil, 366(1-2), 585-603. DOI: https://doi.org/10.1007/s11104-012-1430-1

Sudadi, Widijanto, H., \& Hahsari Efendi Putri, L. (2008). Isolasi Mikroba Asli Tanah Andisol Dieng dan Kajian Potensinya sebagai Inokulan Pupuk Hayati Pelarut Fosfat. Sains Tanah - Jurnal Ilmu Tanah Dan Agroklimatologi, 10(2), 1-10. DOI: https://doi.org/10.24198/ soilrens.v16i1.18317

Uddin, M., Hussain, S., Masroor Akhtar Khan, M., Hashmi, N., Idrees, M., Naeem, M., \& Ahmad DAR, T. (2014). Use of $\mathrm{N}$ and $\mathrm{P}$ biofertilizers reduces inorganic phosphorus application and increases nutrient uptake, yield, and seed quality of chickpea. Turkish Journal of Agriculture and Forestry, 38, 47-54. DOI: https://doi.org/10.3906/tar-1210-36

Wedage, W. M. M., Aberathne, A. H. M. N. R., Harischandra, I. N., \& Gunawardana, D. (2019). A Nodulation-ProficientNonrhizobialInhabitantofPuerariaphaseoloides. HindawiTheScientific World Journal, 2019, 1-9. DOI: https://doi.org/https://doi.org/10.1155/2019/9782684

White, P. J., Bradshaw, J. E., Brown, L. K., Dale, M. F. B., Dupuy, L. X., George, T. S., ... Wright, G. (2018). Juvenile root vigour improves phosphorus use efficiency of potato. Plant and Soil, 432(1-2), 45-63. DOI: https://doi.org/10.1007/s11104-018-3776-5

Yang, P., Zhou, X.-F., Wang, L.-L., Li, Q.-S., Zhou, T., Chen, Y.-K., ... He, B.-Y. (2018). Effect of Phosphate-Solubilizing Bacteria on the Mobility of Insoluble Cadmium and Metabolic Analysis. Internasional Journal of Environmental Research and Public Healt, 15(7), 1-12. DOI: https://doi.org/10.3390/ijerph15071330

Zabee, M. A.-, \& AL-Maliki, S. (2019). Interactions between Biofertilizers and Chemical Fertilizers affected Soil Biological Properties and Potato Yield. Euphrates Journal of Agriculture Science, 11(1). Retrieved from https://www.researchgate.net/profile/Salwan_Al-Maliki2/ publication/332655387_Interactions_between_Biofertilizers_and_Chemical_Fertilizers affected_Soil_Biological_Properties_and_Potato_Yield/links/5cc1f $980 \mathrm{a} 6 \mathrm{fdcc} 1 \mathrm{~d} 49 \mathrm{aef5f9/}$ Interactions-between-Biofertilize 